\title{
Text Analysis within Quantitative and Qualitative Psychotherapy Process Research: Introduction to Special Issue
}

\author{
Omar Carlo Gioacchino Gelo ${ }^{1,2 \bowtie}$, Silvia Salcuni ${ }^{3}$, \& Antonello Colli ${ }^{4}$
}

\begin{abstract}
The present paper introduces the special issue on Text Analysis in Quantitative and Qualitative Psychotherapy Process Research. The motivation for this special issue grew out of recognition of the following: (1) both quantitative and qualitative psychotherapy process research (PPR) make extensive use of text analysis (TA); (2) TA presents different characteristics that serve different aims in quantitative and qualitative PPR; and (3) researchers are not always fully aware of these differences in explicit and systematic ways. The present paper, together with the special issue it introduces, aims at stimulating a more explicit and systematic methodological reflection on the different ways in which TA may be used in quantitative and qualitative PPR. We first outline the general differences between TA in quantitative and qualitative PPR; then, we describe the extent to which the papers in this special issue illustrate these differences. Finally, we conclude by stressing that PPR may significantly benefit from researchers becoming more fully aware of the differences.
\end{abstract}

Keywords: psychotherapy process research, text analysis, quantitative methods, qualitative methods

Psychotherapy Process Research (PPR) consists of the scientific investigation of in-therapy processes and can be performed by means of both quantitative and qualitative research approaches (Elliott, 2010; Hill \& Lambert, 2004; Lutz \& Hill, 2009; Manzo, 2010; Orlinsky, Rønnestad, \& Willutzki, 2004; Rice \& Greenberg, 1984; see also Gelo, Auletta, \& Brakmann, 2010; Gennaro, Venuleo, Auletta, \& Salvatore, 2012; for mixed-methods research combining quantitative and qualitative methods, see Hanson, Creswell, Plano Clark, Petska, \& Creswell, 2005; see also Gelo, Braakmann, \& Benetka, 2008, 2009). This type of research heavily relies on textual material (Greenberg \& Pinsof, 1986; Lepper \& Riding, 2005), which is de-

\footnotetext{
${ }^{1}$ University of Salento, Department of History, Society and Human Studies, Italy.

${ }^{2}$ Sigmund Freud University Vienna, Austria, Department of Psychotherapy Science.

${ }^{3}$ University of Padua, Department of Developmental and Social Psychology, Italy.

${ }^{4}$ University of Urbino, Department of Human Sciences, Italy.

$\square$ Correspondence concerning this article should be addressed to O. Gelo, Palazzo Parlangeli, via Stampacchia 45, 73100 Lecce (LE), Italy. E-mail: omar.gelo@unisalento.it
}

fined here as any material having a linguistic and, eventually, a paralinguistic structure. Such material is, in fact, considered to (potentially) carry a substantial amount of meaningful information about the psychotherapeutic process and is usually derived from either therapeutic sessions or ad-hoc interviews, which are usually audio or video recorded and, in most cases, transcribed.

Text analysis (TA) is used to analyze this textual material. TA may be very generally defined as any set of procedures of inquiry of a text used to draw meaningful information from it with regard to its explicit and/or implicit content, organization, and/or structure. ${ }^{1}$ Within PPR, TA may be approached in several ways and serve different aims, especially in quantitative versus qualitative PPR. Although researchers may (intuitively) acknowledge these differences, they are not always fully aware of them in a systematic and explicit way.

\footnotetext{
${ }^{1}$ The term "content analysis" may be used to refer to both the manifest and latent content of a text (Mayring, 2000) or, alternatively, only to the manifest content (Berelson, 1952). Moreover, note that there is a tendency to associate the term with a (post)positivistic approach to TA (see Silverman, 2011).
} 
In a time of "methodological flexibility and systematic pluralism" (Elliott, 1999, p. 252; see also Slife \& Gantt, 1999), this lack of awareness may prevent PPR from developing. This paper, together with the special issue it introduces, is a contribution intended to stimulate a methodological reflection on the differences in TA in quantitative and qualitative PPR. We begin by outlining the general differences in TA in quantitative and qualitative PPR, with reference to some specific features; then, we describe the extent to which the papers in this special issue illustrate these differences.

\section{Quantitative vs. qualitative PPR and TA}

Quantitative and qualitative PPR are the two main approaches to the empirical investigation of the psychotherapeutic process (Hill \& Lambert, 2004; Lutz \& Hill, 2009; see also Timulak, 2008). Both require procedures for systematically collecting and analyzing empirical data (i.e., information) on in-therapy processes. However, they differ with regard to several issues. At a pragmatic and procedural level (i.e., the research methods), the main difference between them involves the nature (i.e., the symbolic format) of the data that they rely upon to answer the research questions. Quantitative PPR primarily makes use of numerical data, which are analyzed by means of statistical analysis, while qualitative PPR makes use of non-numerical languaged (Polkinghorne, 2005, p. 317) data, which are analyzed using meaning-based forms of data analysis (Elliott, 1999; Hill \& Lambert, 2004; Lutz \& Hill, 2009). ${ }^{2}$ It is due to these differences that TA presents different characteristics and serves different aims in quantitative and qualitative PPR. These differences are summarized in Table 1.

Within quantitative PPR, TA is used to collect data in a numerical format. This is the case when quantitative observational data collection instruments are applied by raters to audio/video recordings or transcripts of therapy sessions (see Mergenthaler \& Stinson, 1992); in some minor cases, ad-hoc interviews are also used as sources of material (for an overview, see Barker, Pistrang, \& Elliott, 2002; Greenberg \& Pinsof, 1986; Lepper \& Riding, 2005). ${ }^{3}$

Examples of quantitative observational instruments are category systems (e.g. the Core Conflict-

\footnotetext{
${ }^{2}$ Actually, the difference between quantitative and qualitative approaches in psychotherapy research goes beyond the research methods; it also involves the methodological principles underlining these methods and the worldviews grounding them. We direct the reader to Ponterotto (2005) for a more general discussion of these issues in the field of psychotherapy research (see also Gelo, 2012 and Polkhingorne, 1983, for a similar discussion regarding the general social sciences).

${ }^{3}$ Another main way to collect numerical data in quantitative PPR is through the use of quantitative self-reports, in which subjects directly provide their responses by rating items on a scale (e.g., the Working Alliance Inventory [Horvath \& Greenberg, 1989], Session Reports [Orlinsky \& Howard, 1986]).
}

ual Relationship Theme [Luborsky et al., 1994], the Verbal Response Modes [Elliott et al., 1987], the Collaborative Interactions Scale [Colli \& Lingiardi, 2007, 2009]), rating scales (e.g. the Defense Mechanism Rating Scale [Perry, 1990], the Comparative Psychotherapy Process Scale [Hilsenroth, Blagys, Ackerman, Bonge, \& Blais, 2005], the Assimilation of Problematic Experiences Scale [Stiles et al., 1990]), Q-sort techniques (e.g. the Psychotherapy Process Q-Sort [Ablon, Levy, \& Smith-Hansen, 2011; Jones, 2000; Lingiardi, Bonalume, Colli, Gentile, \& Tanzilli, 2011]), and other types of coding systems (e.g. the Adult Attachment Interview [Main, Hesse, \& Goldwyn, 2008]). ${ }^{4}$ These and some other examples of observational instruments used in quantitative PPR are reported in Table 1.

These instruments allow for the assessment of the investigated text with regard to a limited set of previously defined theoretical constructs (i.e., relational patterns, response modes, defenses, metacognitive functions, etc.), thus adopting a theory-driven approach to TA. Thus, each of these instruments specifies both the construct (i.e., category) assessed in the text (e.g., different relational patterns, defenses, etc.) and the textual characteristic that may indicate the presence of the construct. The TA involved in the application of these instruments is mainly focused on the speech content, although some other aspects of textual organization (e.g., speech coherence) may be considered (e.g., in the case of the AAI). The categories are explicitly defined, usually in a manual, and text passages prototypical of those categories are provided as examples to "guide" the rater in the application of the instrument. Then, the eventual presence of a construct in the text is coded by the rater on a dichotomous, nominal, or Likert scale.

Finally, specific procedures of inter-rater reliability are applied, in which codings by different raters are compared by numerically calculating the degree of agreement among them (Hill \& Lambert, 2004). This type of TA represents a standardized version of what has been described as deductive content analysis (Elo \& Kyngäs, 2008; Mayring, 2000; see also Berelson, 1952). The ratings provided by the raters will constitute the numerical data that will be then used in the statistical analysis to answer the research questions of the study (see Pokorny, Gelo, \& Moertl, in prep.; see the special issue of Lutz \& Lambert, 2009, for some examples of the most recent

\footnotetext{
${ }^{4}$ Strictly speaking, attachment as assessed by the Adult Attachment Interview (AAI) is more of an input or output variable than a process variable (see Orlinsky et al., 2004). However, considering the relevance that attachment may have for the therapeutic process (e.g., Steele, Steele, \& Murphy, 2009), we decided to consider the AAI as an instrument ascribable to (quantitative) PPR.
} 
Table 1. Some common features distinguishing between TA in quantitative and qualitative PPR

\begin{tabular}{|c|c|c|}
\hline Feature & TA in quantitative PPR & TA in qualitative PPR \\
\hline Scope & Data collection & Data analysis \\
\hline \multirow{29}{*}{$\begin{array}{l}\text { Focus and examples of } \\
\text { methods }\end{array}$} & Speech content & Participants'subjective experiences \\
\hline & Core Conflictual Relationship Themes & Grounded Theory Analysis (Glaser \& \\
\hline & $\begin{array}{l}\text { (Luborsky et al., 1994) } \\
\text { Verbal Response Modes (Elliott et al. }\end{array}$ & $\begin{array}{l}\text { Strauss, 1967; Strauss \& Corbin, 1998) } \\
\text { Phenomenological Analysis (Giorgi, 2009; }\end{array}$ \\
\hline & $1987)^{\mathrm{a}}$ & Smith, 1996) \\
\hline & $\begin{array}{l}\text { Structural Analysis of Social behavior } \\
(\text { Benjamin et al., 2006) }\end{array}$ & $\begin{array}{l}\text { Narrative Analysis (Avdi \& Georgaca, } \\
\text { 2007a) }\end{array}$ \\
\hline & $\begin{array}{l}\text { Generic Change Indicators (Krause et al., } \\
2007)^{a}\end{array}$ & $\begin{array}{l}\text { Biographical Analysis (Riemann \& } \\
\text { Schuetze, 1991) }\end{array}$ \\
\hline & $\begin{array}{l}\text { Innovative Moments Coding System } \\
\text { (Gonçalves et al., 2009) }^{\mathrm{a}}\end{array}$ & $\begin{array}{l}\text { Consensual Qualitative Research (Hill et } \\
\text { al., 1997) }\end{array}$ \\
\hline & $\begin{array}{l}\text { Dynamic Mapping of the Structures of } \\
\text { Content (Salvatore et al., 2012) }\end{array}$ & $\begin{array}{l}\text { Thematic Analysis (Braun \& Clarke, } \\
\text { 2006) }\end{array}$ \\
\hline & $\begin{array}{l}\text { Therapeutic Activity Coding System } \\
\text { (Valdés et al., 2010) }\end{array}$ & $\begin{array}{l}\text { Inductive Content Analysis (Mayring, } \\
\text { 2000) }\end{array}$ \\
\hline & $\begin{array}{l}\text { Narrative Process Coding system (Angus et } \\
\text { al., 1999) }\end{array}$ & Pragmatics, functions or structure of \\
\hline & Grid of the Models of Interpretation & language-in-use \\
\hline & $\left(\right.$ Auletta et al., 2012) ${ }^{\mathrm{a}}$ & Conversation Analysis (Madill, 2001) \\
\hline & $\begin{array}{l}\text { Assessment of Interpersonal Motivation in } \\
\text { Transcripts (Fassone et al., 2012) }\end{array}$ & $\begin{array}{l}\text { Discourse Analysis (Avdi \& Georgaca, } \\
\text { 2007b) }\end{array}$ \\
\hline & $\begin{array}{l}\text { Defense Mechanisms Rating Scale (Perry, } \\
1990)^{\mathrm{b}}\end{array}$ & Clinical processes \\
\hline & $\begin{array}{l}\text { Metacognition Assessment Scale (Semerari } \\
\text { et al., 2003) }\end{array}$ & $\begin{array}{l}\text { Task Analysis (discovery phase) } \\
\text { (Greenberg, 2007) }\end{array}$ \\
\hline & $\begin{array}{l}\text { Comparative Psychotherapy Process Scale } \\
\text { (Hilsenroth et al., 2005) }\end{array}$ & \\
\hline & Comprehensive Psychotherapy & Assimilation Analysis (Stiles et al., 1992) \\
\hline & $\begin{array}{l}\text { Intervention Rating Scale (Trijsburg et } \\
\text { al., 2002) }\end{array}$ & Metaphor Analysis (Buchholz, 1993) \\
\hline & $\begin{array}{l}\text { Motivational Areas Rating Scale (Sarracino } \\
\text { \& Dazzi, 2007) }\end{array}$ & \\
\hline & Collaborative Interactions Scale (Colli \& & \\
\hline & Lingiardi, 2009) ${ }^{\mathrm{b}}$ & \\
\hline & Referential Activity (Bucci et al., 1992) & \\
\hline & Assimilation of Problematic Experiences & \\
\hline & Scale (Stiles et al., 1990) ${ }^{\mathrm{b}}$ & \\
\hline & Psychotherapy Process Q-Sort (2000) ${ }^{c}$ & \\
\hline & $\begin{array}{l}\text { Adult Attachment Interview (Main et al., } \\
\text { 2008) }\end{array}$ & \\
\hline & Speech organization & \\
\hline & $\begin{array}{l}\text { Assessment of Interpersonal Motivation in } \\
\text { Transcripts (Fassone et al., 2012) }\end{array}$ & \\
\hline & $\begin{array}{l}\text { Adult Attachment Interview (Main et al., } \\
\text { 2008) }\end{array}$ & \\
\hline Strategy of analysis & Theory-driven, top-down & Data-driven/theory-informed, cyclical \\
\hline Logical operations involved & Deduction & Eduction, abduction, induction, deduction \\
\hline $\begin{array}{l}\text { Type and amount of } \\
\text { categories worked with }\end{array}$ & Preset, limited & Emergent, variable \\
\hline \multirow[t]{2}{*}{ Quality criteria } & \multirow[t]{2}{*}{ Inter-rater reliability (Cohen's $K, \mathrm{ICC})^{\mathrm{d}}$} & Demonstrative rhetoric (use of examples) \\
\hline & & $\begin{array}{l}\text { Consensus (group discussion, peer review, } \\
\text { audit, debriefing) }\end{array}$ \\
\hline Prototypical reference & Deductive content analysis & Methodical hermeneutics \\
\hline
\end{tabular}

Note. $\mathrm{TA}=$ text analysis. $\mathrm{PPR}=$ psychotherapy process research. $\mathrm{ICC}=$ intra-class correlation.

${ }^{a}$ Category system. ${ }^{b}$ Rating scale. ${ }^{c}$ Q-sort technique. ${ }^{d}$ Coding system. 
advancements). ${ }^{5}$

On the other hand, in qualitative PPR, TA represents the core of the data analysis process that is necessary for answering the research questions of the study. In fact, in this type of PPR, data are already collected in a languaged format by recording therapy sessions (see Mergenthaler \& Stinson, 1992; Sack, Schegloff, \& Jefferson, 1974) and/or through ad-hoc interviews (see Knox \& Burkard, 2009). In some cases, audio/video assisted recall procedures are used in combination with interviews, as in Interpersonal Process Recall (IPR; Elliott, 1986; for an overview, see Barker et al., 2002; Blasi, 2010; Elliott, Slatick, \& Urman, 2001). Three main types of TA may be used within qualitative PPR (see Rennie, 2012; for an overview, see Frommer \& Rennie, 2001; Madill \& Gough, 2008; Mcleod, 2011; Moertl, Gelo, \& Pokorny, in prep.): experiential TA, which focuses on the subjective experiences of the participants; discursive TA, focusing on the pragmatics, functions or structure of the languagein-use; and experiential/discursive TA, entailing focus on either the experience or the discourse with the aim of a clinically meaningful analysis of one or more cases. Examples of experiential TA are Grounded Theory Analysis (Glaser \& Strauss, 1967; Strauss \& Corbin, 1998), Descriptive and Interpretative Phenomenological Analysis (Giorgi, 2009; Smith, 1996), Narrative Analysis (Avdi \& Georgaca, 2007a; McLeod \& Balmoutsou, 2006), Biographical Analysis (Riemann \& Schuetze, 1991), ${ }^{6}$ Consensual Qualitative Research methods (Hill, Thompson, \& Williams, 1997) and, to some extent, Inductive Content Analysis (Elo \& Kyngäs, 2008; Mayring, 2000) and Thematic Analysis (Braun \& Clarke, 2006). ${ }^{7}$ Examples of discursive TA are Conversation Analysis (Lepper, 2000; Madill, 2001; Peräkylä, Antaki, Vehviläinen, \& Leudar, 2008) and Discourse Analysis (Avdi \& Georgaca, 2007b). Examples of experiential/discursive TA are the discovery phase of Task Analysis (Greenberg, 2007), Comprehensive Process Analysis (Elliott, 1989), Assimilation Analysis (Stiles, Meshot, Anderson, \&

\footnotetext{
${ }^{5}$ Computer-assisted TA procedures may also be used to collect numerical data within quantitative PPR (e.g., the Therapeutic Cycle Model [Mergenthaler, 1996, 2008], the Referential Activity [Bucci \& Maskit, 2006; Mergenthaler \& Bucci, 1999], and the Automated Co-occurrence Analysis for Semantic Mapping [Salvatore, Gennaro, Auletta, Tonti, \& Nitti, 2011]). Although these procedures may share some of the features of TA described so far, they present high degrees of specificity. For this reason, we decided to exclude them from consideration in this special issue.

${ }^{6}$ The biography of a subject is not necessarily related to treatment in-session processes. However, considering the potential mutual interconnections that can occur between a life trajectory and in-session processes, we decided to consider Biographical Analysis a method ascribable to (qualitative) PPR.

${ }^{7}$ Unlike Rennie (2012), we consider Thematic Analysis an experiential type of TA. However, we acknowledge that the subjective experience that can be depicted and reconstructed through Thematic Analysis is rather superficial compared to other experiential methods.
}

Sloan, 1992 $)^{8}$ and Systematic Metaphor Analysis (Buchholz, 1993; Schmitt, 2005; for a slightly different approach, see Gelo \& Mergenthaler, 2012).

The interpretation required to conduct this type of TA goes far beyond what is required to deductively apply a standardized set of categories to a text, as in the case in quantitative PPR. In fact, TA used in qualitative PPR involve a much deeper and more thorough cyclical interaction between the analyzer and the text (see hermeneutic circle; Dilthey, 1996). Within this process, eduction (Rennie, 2012) and abduction (Haig, 2005, 2008; Salvatore \& Valsiner, 2010) cyclically interact with induction and deduction, and a variable number of emergent patterns of experience, language use, or clinically significant processes may be identified within the text under analysis. Finally, the trustworthiness or credibility of the analysis (see Elliott, Fischer, \& Rennie, 1999; Nutt, Williams, \& Morrow, 2009) is, in many cases, demonstrated rhetorically (Rennie, 2012). That is, the researcher conducting the TA grounds his or her arguments for the identification of specific textual patterns (of experience, language use, or clinical process) on the discussion of typical examples that are persuasive. In some other cases, a greater emphasis may be placed upon intersubjective interpretative agreement, which is achieved by means of group discussions and, eventually, external audits, peer reviews, and debriefing. The features of TA found in qualitative PPR are consistent with what Rennie (2012) calls methodical hermeneutics.

\section{TA in quantitative PPR: Narrative processes, innovative moments, communicative intentions, and attachment}

The first four contributions of this special issue illustrate quantitative approaches to PPR making use of TA; the commonalities and the differences between them are summarized in Table 2. Each of these papers is characterized by a specific topic. Angus et al. (2012) review the application of the Narrative Process Coding System (NPCS) to emotion-focused therapy for depression and show how this allowed investigating the relationship between different narrative modalities, in-session process variables, and treatment outcomes. Cunha, Spínola, and Gonçalves (2012) make use of the Innovative Moments Coding System (IMCS) to assess, in both good and poor outcome cases of narrative therapy for depression, different types of Innovative Moments (IMs), as well as different modalities of their emergence. Associations between these variables and differences in the two cases are analyzed. Dagnino, Krause, Pérez, Valdés, and Tomicic (2012) apply the Therapeutic Activity Coding System (TACS) to assess different types of clients' and therapists' communicative intentions during change

\footnotetext{
${ }^{8}$ Assimilation Analysis is usually used to identify the client's voices as a preliminary step to the application of the APES (Osatuke \& Stiles, 2011).
} 


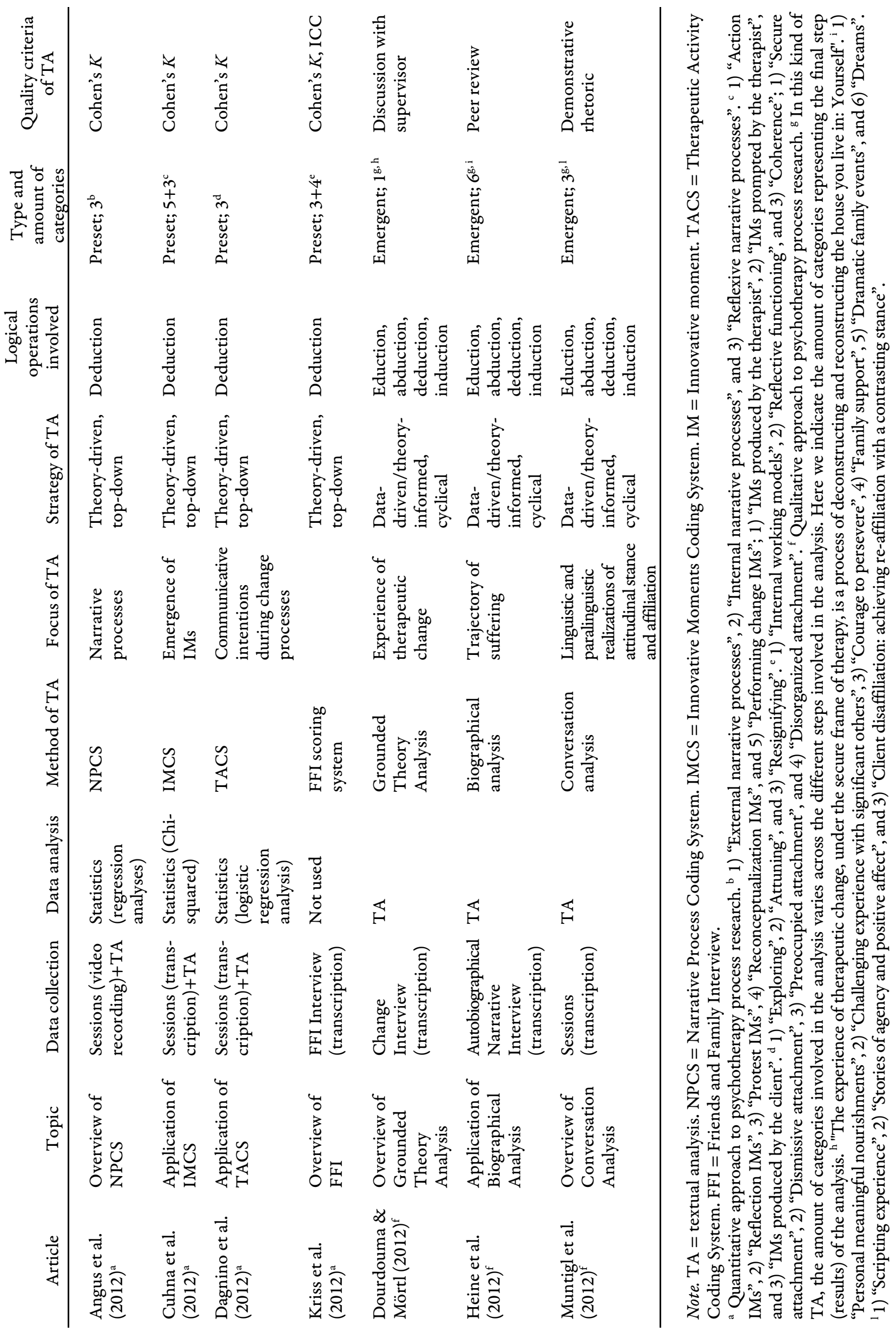


episodes in psychotherapies with different orientations. Differences between clients' and therapists' communicative intentions, as well as their temporal courses, are analyzed. Finally, Kriss, Steele, and Steele (2012) introduce the Family and Friends Interview (FFI), which represents both a semi-structured interview protocol to collect attachment-relevant information and a rating system assessing attachment in middle and late childhood. The authors describe the theoretical background of the FFI and the methodology of rating.

Notwithstanding these differences, these four papers share many commonalities. They all use TA in their quantitative data collection, which is performed either by means of a category system (NPCS, IMCS, or TACS) applied to the audio recordings (Angus et al., 2012) or transcripts (Cunha et al., 2012; Dagnino et al., 2012) of sessions or by means of a rating scale (FFI) applied to transcripts of ad-hoc interviews (Kriss at al., 2012). The data collected in this way are then analyzed, using either parametric or nonparametric statistics, to answer the research questions addressed in each paper. The only exception is the paper by Kriss et al. (2012), which focused on the theoretical background and rating procedure of the FFI without reference to the statistics that might be used with the scores obtained from the application of the instrument (for the application of statistics to relate attachment-relevant variables to in-process variables, see, for example, Saypol \& Farber, 2010).

Moreover, all of the instruments presented or applied in these four contributions follow a theorydriven, top-down approach to TA, which consists, in the deductive application of a previously defined and limited number of categories to be rated on nominal (Angus et al., 2012; Cuhna et al., 2012; Dagnino et al., 2012) and/or Likert (Kriss et al., 2012) scale(s). Finally, the reliability of the TA is assessed using numerical coefficients. In the case of nominal ratings (such as on the NPCS, IMCS, TACS, and part of the FFI), Cohen's (1960) kappa is used (Angus et al., 2012; Cuhna et al., 2012; Dagnino et al., 2012; Kriss et al., 2012), while the intra-class correlation coefficient (Shrout \& Fleiss, 1979) is used for Likert scale ratings (as on part of the FFI; Kriss et al., 2012).

\section{TA in qualitative PPR: Experience of therapeutic change, trajectories of suffering, and attitudinal stance and affiliation}

The last three contributions of this special issue illustrate TA employed in qualitative PPR. Table 2 summarizes the commonalities and the differences among them. Each of these papers is characterized by a specific topic. Dourdouma and Mörtl (2012) provide a methodological overview of Grounded Theory Analysis, along with a set of guidelines for its application; concrete examples are given, with reference to the investigation of the experience of change in clients who have undergone systemic family therapy. Heine, Schütze, Köhler, and Frommer (2012) make use of Biographical Analysis to investigate the trajectory of suffering among leukemia survivors and identify different modalities of coping with it. Finally, Muntigl, Knight, Horvath, and Watkins (2012) provide an overview of one specific approach to Conversation Analysis for the investigation of client attitudinal stance and therapist-client affiliation. Excerpts from couples therapy and from one individual therapy case with a depressed client are analyzed to provide examples of the application of this method.

Notwithstanding these differences, these three papers share many commonalities that clearly distinguish them from those presented in the previous section. First of all, TA here represents the procedure of data analysis, which is necessary to answer the research questions of each study; the languaged data are collected by transcribing ad-hoc interviews (Dourdouma \& Mörtl, 2012; Heine et al., 2012) or therapy sessions (Muntigl et al., 2012).

Moreover, all of the different methodologies presented or applied in these three contributions follow a data-driven/theory-informed approach to TA, in which eduction, abduction, deduction, and induction interact differently with each other. This allows the researcher(s) to identify variable numbers of emergent patterns regarding clients' experiences of therapeutic change (Dourdouma \& Mörtl, 2012), autobiographical trajectories of suffering and the related coping strategies (Heine et al., 2012), and/or linguistic and paralinguistic realizations of attitudinal stance and affiliation (Muntigl, 2012). Finally, the credibility of the analyses is supported, whether by means of regular discussions with a supervisor (Dourdouma \& Mörtl, 2012) or research team (Heine et al., 2012) or by means of demonstrative rhetoric (Muntigl et al., 2012).

\section{Conclusion}

To investigate in-session psychotherapeutic processes, both quantitative and qualitative PPR make extensive use of TA. Taken together, the papers reviewed in this special issue display the extent to which TA may be differently used in each of these two empirical approaches to PPR. We believe that being explicitly and systematically aware of these differences can significantly contribute to the further development of methodological flexibility and pluralism and that PPR will benefit from such awareness. In agreement with Lutz and Hill (2009, p. 372), we hope that this special issue will stimulate not only better PPR by means of TA but also more research on TA itself.

\section{Acknowledgement}

We would like to thank Valeria Condino and Daniela Gentile for their support in preparing this manuscript.

\section{References}

Ablon, J. S., Levy, R. A., Smith-Hansen, L. (2011). The Contributions of the Psychotherapy Process Q-set to Psychotherapy Research. Research in Psychotherapy: Psychopathology, 
Process and Outcome, 14(2), 14-48.

Angus, L., Lewin, J., Boritz, T., Bryntwick, E., Carpenter, N., Watson-Gaze, J., \& Greenberg, L. (2012). Narrative Processes Coding System: A Dialectical Constructivist approach to assessing client change processes in Emotion-focused therapy of depression. Research in Psychotherapy: Psychopathology, Process and Outcome, 15(2), 54-61. doi: 10.7411/RP.2012.006

Angus, L., Levitt, H., \& Hardtke, K. (1999). The Narrative Processes Coding System: Research applications and implications for psychotherapy practice. Journal of Clinical Psychology, 55(10), 1255-1270. doi: 10.1002/(SICI)10974679(199910)55:10<1255::AID-JCLP7>3.0.CO;2-F

Auletta, A. F., Salvatore, S., Metrangolo, R., Monteforte, G., Pace, V., Puglisi, M. (2012). The Grid of the Models of Interpretations (GMI): A trans-theoretical method to study therapist interpretive activity. Journal of Psychotherapy Integration, 22(2), 61-84. doi: 10.1037/a0028009

Avdi, E., \& Georgaca, E. (2007a). Narrative research in psychotherapy: A critical review. Psychology and Psychotherapy: Theory, Research and Practice, 80(3), 407-419. doi:10.1348/147608306X158092

Avdi, E., \& Georgaca, E. (2007b). Discourse analysis and psychotherapy: A critical review. European Journal of Psychotherapy, Counselling \& Health, 9(2), 157-176. doi: 10.1080/13642530701363445

Barker, C., Pistrang, N., \& Elliott., R. (2002). Research methods in clinical psychology: An introduction for students and practitioners (2nd ed.). New York: Wiley.

Benjamin, L. S., Rothweiler, J. C., \& Critchfield, K. L. (2006). The use of Structural Analysis of Social Behavior (SASB) as an assessment tool. Annual Review of Clinical Psychology, 2, 83-109.

Berelson, B. (1952). Content analysis in communication research. Glencoe, Ill.: Free Press.

Blasi, S. (2010). La ricerca qualitativa in psicoterapia. Controversie, applicazioni e "criteri di qualita". Ricerca in Psicoterapia/Research in Psychotherapy: Psychopathology, Process and Outcome, 13(1), 23-60.

Braun, V., \& Clarke, V. (2006). Using thematic analysis in psychology. Qualitative Research in Psychology, 3, 77-101. doi:10:1191/ 1478088706qp063oa

Buchholz, R. A. (1993). Metaphernanalyse [Metaphor Analysis]. Göttingen: Vandenhoeck \& Ruprecht.

Bucci, W., Kabasakalian, R. \& the RA Research Group (1992). Instructions for scoring Referential Activity $(R A)$ in transcripts of spoken narrative texts. Ulm, Germany; Ulmer Textbank.

Bucci, W., \& Maskit, B. (2006). A weighted dictionary for Referential Activity. In J. G. Shanahan, Y. Qu \& J. Wiebe (Eds.), Computing attitude and affect in text (pp. 49-60). Dordrecht, The Netherlands: Springer.

Cohen, J. (1960). A coefficient of agreement for nominal scales. Educational and Psychological Measurement, 20, 37-46.

Colli, A., \& Lingiardi, V. (2007a). Valutare l'alleanza terapeutica attraverso trascritti di sedute: l'attendibilità della IVAT-R nello studio di quattro psicoterapie. Ricerca in psicoterapia, 10(1), 75-97.

Colli, A., \& Lingiardi, V. (2009). The Collaborative Interactions Scale: A new transcript-based method for the assessment of therapeutic alliance ruptures and resolutions in psychotherapy. Psychotherapy Research, 19(6), 718-734. doi:10.1080/10503300903121098

Cunha, C. A. C., Spínola, J., \& Gonçalves, M. M. (2012). The emergence of innovative moments in narrative therapy for depression: Exploring therapist and client contributions. Research in Psychotherapy: Psychopathology, Process and Outcome, 15(2), 62-74. doi: 10.7411/RP.2012.007

Dagnino, P., Krause, M., Pérez, C., Valdés, N., \& Tomicic, A. (2012). The evolution of communicative intentions during change episodes and throughout the therapeutic process. $R e-$ search in Psychotherapy: Psychopathology, Process and Outcome, 15(2), 75-86. doi: 10.7411/RP.2012.008

Dilthey, W. (1996). Hermeneutics and its history. In R. A. Makkreel \& F. Rodi (Eds.), Wilhelm Dilthey: Selected works: Vol. 4: Hermeneutics and the study of history (pp. 233-258). Princeton, NJ: Princeton University Press.

Dourdouma, A., \& Mörtl, K. (2012). The creative journey of grounded theory analysis: A guide to its principles and applications. Research in Psychotherapy: Psychopathology, Process and Outcome, 15(2), 96-106. doi: 10.7411/RP.2012.010

Elliott, R. (1986). Interpersonal Process Recall (IPR) as a psychotherapy process research method. In L. Greenberg \& W. Pinsof (Eds.), The Psychotherapeutic process: A Research Handbook (pp. 503-527). New York: Guilford.

Elliott, R. (1989). Comprehensive process analysis: Understanding the change process in significant therapy events. In M. J. Packer \& R. B. Addison (Eds.), Entering the circle: Hermeneutic investigation in psychology (pp. 165-184). Albany, NY: SUNY Press.

Elliot, R. (1999). Editor's introduction to special issue on qualitative psychotherapy research: definitions, themes and discoveries. Psychotherapy Research, 9(3), 251-257.

Elliott, R. (2010). Psychotherapy change process research: Realizing the promise. Psychotherapy Research, 20, 123-135.

Elliott, R., Hill, C. E., Stiles, W. B., Friedlander, M. L., Mahrer, A. R., \& Margison, F. R. (1987). Primary therapist response modes: Comparison of six rating systems. Journal of Consulting and Clinical Psychology, 55(2), 218-223.

Elliott, R., Slatick, E., \& Urman, M. (2001). Qualitative change process research on psychotherapy: Alternative strategies. In J. Frommer \& D. Rennie (Eds.), Qualitative psychotherapy research: Methods and methodology (pp. 69-111). Lengerich: Pabst Science Publishers.

Fassone, G., Valcella, F., Pallini, S., Scarcella, F., Tombolini, L., ... \& Italian Group for Study of Interpersonal Motivation (2012). Assessment of Interpersonal Motivation in Transcripts (AIMIT): An inter- and intra-rater reliability study of a new method of detection of interpersonal motivational systems in psychotherapy. Clinical Psychology and Psychotherapy, 19(3), 224-34. doi: 10.1002/cpp.742

Elo, S., \& Kyngäs, H. (2008), The qualitative content analysis process. Journal of Advanced Nursing, 62(1), 107-115. doi: 10.1111/j.1365-2648.2007.04569.x

Frommer, J., \& Rennie, D. (Eds.). (2001). Qualitative psychotherapy research: Methods and methodology. Lengerich: Pabst Science Publishers.

Gelo, O. (2012). On research methods and their philosophical assumptions: "Raising the consciousness of researchers" again. Psychotherapie und Sozialwissenschaft, 14(2), 111-130.

Gelo O., Auletta, A., \& Braakmann, D. (2010). Theoretical, methodological and data analytical issues in Psychotherapy Research. Part I: Outcome and Process Research - from the 50s to the 80s. Ricerca in Psicoterapia/Research in Psychotherapy: Psychopathology, Process and Outcome, 13(1), 61-91.

Gelo O., Braakmann, D., \& Benetka, G. (2008). Quantitative and qualitative research: Beyond the debate. Integrative Psychological and Behavioural Science, 42(3), 266-290. doi: 10.1007/s12124-008-9078-3

Gelo, O., Braakmann, D., \& Benetka, G. (2009). Erratum to "Quantitative and qualitative research: Beyond the debate". Integrative Psychological and Behavioural Science, 43(4), 406407. doi: $10.1007 /$ s12124-009-9107-x

Gelo, O. C. G., \& Mergenthaler, E. (2012). Unconventional metaphors and emotional-cognitive regulation in a metacognitive interpersonal therapy. Psychotherapy Research, 22(2), 159-175. doi: 10.1080/10503307.2011.629636

Gennaro, Venuleo, Auletta, \& Salvatore, (2012). The Topics of Psychotherapy Research: An Analysis Based on Keywords. 
Research in Psychotherapy: Psychopathology, Process and Outcome, 15(1), 1-9. doi: 10.7411/RP.2012.001

Giorgi, A. (2009). The descriptive phenomenological method in psychology: A modified Husserlian approach. Pittsburgh, PA: Duquesne University Press.

Glaser, B. G., \& Strauss, A. (1967). The discovery of grounded theory: Strategies for qualitative research. Chicago. IL: Aldine.

Gonçalves, M. M., Matos, M., \& Santos, A. (2009). Narrative therapy and the nature of "innovative moments" in the construction of change. Journal of Constructivist Psychology, 22, 1-23. doi: 10.1080/10720530802500748

Greenberg, L. (2007). A guide to conducting a task analysis of psychotherapeutic change. Psychotherapy Research, 17(1), 15-30.

Greenberg, L. S., \& Pinsof, W. M. (1986). The psychotherapeutic process: $A$ research handbook. New York: Guilford Press.

Haig, B. (2005). An abductive theory of scientific method. Psychological Methods, 10, 371-388. doi:10.1037/1082989X10.4.371

Haig, B. (2008a). On the permissiveness of the abductive theory of method. Journal of Clinical Psychology, 64, 1037-1045. doi:10.1002/jclp.20507

Hanson, W. E., Creswell, J. W., Plano Clark, V. L., Petska, K. S., \& Creswell, J. D. (2005). Mixed methods research designs in counseling psychology. Journal of Counseling Psychology, 52(2), 224-235.

Heine, V., Schütze, F., Köhler, M., \& Frommer, J. (2012). From life-threatening experiences to ideas of rescue: coping with trajectories of suffering in adult acute leukaemia survivors. Research in Psychotherapy: Psychopathology, Process and Outcome, 15(2), 107-116. doi: 10.7411/RP.2012.011

Hilsenroth, M. J., Blagys, M. D., Ackerman, S. J., Bonge, D. R., \& Blais, M. A. (2005). Measuring PsychodynamicInterpersonal and Cognitive-Behavioral Techniques: Development of the Comparative Psychotherapy Process Scale. Psychotherapy: Theory, Research, Practice, Training, 42(3), 340-356. doi: 10.1037/0033-3204.42.3.340

Hill, C. E., \& Lambert, M. (2004). Methodological issues in studying psychotherapy processes and outcomes. In M. J. Lambert (Ed.), Bergin and Garfield's handbook of psychotherapy and behavior change (pp. 84-135). New York: John Wiley \& Sons.

Hill, C. E., Thompson, B. J., \& Williams, E. N. (1997). A guide to conducting consensual qualitative research. The Counseling Psychologist, 25, 517-572. doi:10.1177/0011000097254005

Horvath, A. O., Greenberg, L. S. (1989). Development and validation of the Working Alliance Inventory. Journal of Counseling Psychology, 36(2), 223-233. doi: 10.1037/00220167.36.2.223

Jones, E.E. (2000). Therapeutic Action. A guide of psychoanalytic therapy. Northvale, NJ: Jason Aronson.

Knox, S., \& Burkard, A. W. (2009). Qualitative research interviews. Psychotherapy Research, 19, 566-75.

Krause, M., de la Parra, G., Arístegui, R., Dagnino, P., Tomicic, A., ... \& Ramirez, I. (2007) The evolution of therapeutic change studied through generic change indicators. Psychotherapy Research, 17, 673-689. doi: 10.1080/10503300601158814

Kriss, A., Steele, H., \& Steele, M. (2012) Measuring attachment and reflective functioning in early adolescence: An introduction to the Friends and Family Interview. Research in Psychotherapy: Psychopathology, Process and Outcome, 15(2), 87-95. doi: 10.7411/RP.2012.009

Lepper, G. (2000). Categories in text and talk: A practical introduction to categorization analysis. London: Sage Publications.

Lepper, G., \& Riding N. (2005). Researching the psychotherapy process: A practical guide to the methods. London: Palgrave Macmillan.

Lingiardi, V., Bonalume, L., Colli, A., Gentile, D., \& Tanzilli, A. (2011). The Psychotherapy Process Q-set from the Perspec- tive of the Italian Research in Psychotherapy: Commentary on a Paper by J. Stuart Ablon, Raymond A. Levy, and Lotte Smith-Hansen. Research in Psychotherapy: Psychopathology, Process and Outcome, 14(2), 24-42.

Luborsky, L., Popp, C., Luborsky, E., \& Mark, D (1994). The Core Conflictual Relationship Theme. Psychotherapy Research, 4(3-4), 172-183.

Lutz, W., \& Hill, C. E. (2009), Quantitative and qualitative methods for psychotherapy research: Introduction to special section. Psychotherapy Research, 19(4-5), 369-73.

Madill, A., \& Gough, B. (2008). Qualitative research and its place in psychological science. Brendan Psychological Methods, 13(3), 254-271. doi: 10.1037/a0013220

Madill, A., Widdicombe, S., \& Barkham, M. (2001). The potential of conversation analysis for psychotherapy research. The Counseling Psychologist, 29, 413-434.

Main, M., Hesse, E., \& Goldwyn, R. (2008). Studying differences in language usage in recounting attachment history: An introduction to the AAI. In H. Steele \& M. Steele (Eds.), Clinical applications of the Adult Attachment Interview (1st ed., pp. 31-68). New York: The Guilford Press.

Manzo, S. (2010). La ricerca di processo nel decennio 1998-2007: Contributo a una review critica. Research in Psychotherapy: Psychopathology, Process and Outcome, 13(1), 92-119.

Mayring, P. (2000). Qualitative Content Analysis.Forum Qualitative Sozialforschung/Forum: Qualitative Social Research, 1(2), Art. 20. Retrieved form http://nbnresolving.de/urn:nbn:de:0114-fqs0002204

McLeod, J. (2011). Qualitative research in counseling and psychotherapy (2nd ed.). London: Sage Publications.

McLeod, J., \& Balamoutsou, S. (2006). A method for qualitative narrative analysis of psychotherapy transcripts. In J. Frommer \& D. L. Rennie (Eds.), Qualitative psychotherapy research: Methods and methodology (2nd ed., pp. 128-152). Lengerich, Germany: Pabst Science.

Mergenthaler, E. (1996). Emotion-abstraction patterns in verbatim protocols: A new way of describing psychotherapeutic processes. Journal of Consulting and Clinical Psychology, 64, 1306-1315.

Mergenthaler, E. (2008). Resonating minds: A schoolindependent theoretical conception and its empirical application to psychotherapeutic processes. Psychotherapy Research, 18, 109-126.

Mergenthaler, E., \& Bucci, W. (1999). Linking verbal and nonverbal representations: Computer analysis of Referential Activity. British Journal of Medical Psychology, 72, 339-354.

Mergenthaler, E., \& Stinson C. H. (1992). Psychotherapy transcription standards. Psychotherapy Research, 2(2), 125-42.

Moertl, K., Gelo, O., \& Pokorny, D. (in prep.). Qualitative research methods in psychotherapy. In O. Gelo, Pritz, A. \& B. Rieken (Eds.), Psychotherapy research: General issues, process and Outcome. Vienna/New York: Springer.

Muntigl, P., Knight, N., Horvath, A. O., \& Watkins, A. (2012). Client attitudinal stance and therapist-client affiliation: A view from grammar and social interaction. Research in Psychotherapy: Psychopathology, Process and Outcome, 15(2), 117-130. doi: 10.7411/RP.2012.012

Orlinsky, D. E., Rønnestad, M. H., \& Willutzki, U. (2004). Fifty years of process-outcome research: Continuity and change. In M. J. Lambert (Ed.), Bergin and Garfield's handbook of psychotherapy and behavior change (5th ed., pp. 307-390). New York: Wiley.

Orlinsky, D. E., \& Howard, K. I. (1986). The psychological interior of psychotherapy: Explorationswith the therapy session reports. In L. S. Greenberg \& W. M. Pinsof (Eds.), The psychotherapeutic process: $A$ research handbook. New York: Guilford Press.

Osatuke, K., \& Stiles, W. B. (2011). Numbers in assimilation research. Theory \& Psychology, 21(2), 200-219. 
Peräkylä, A., Antaki, C., Vehviläinen, S., \& Leudar, I. (Eds.). (2008). Conversation Analysis and psychotherapy. Cambridge: Cambridge University Press.

Perry, J. C. (1990). Defense Mechanisms Rating Scale. Unpublished manuscript, Cambridge Hospital, Harvard Medical School, Boston.

Pokorny, D., Gelo, O., \& Moertl, K. (in prep.). Quantitative research methods in psychotherapy. In O. Gelo, A. Pritz, \& B. Rieken (Eds.), Psychotherapy research: General issues, process and outcome. Vienna/New York: Springer.

Polkinghorne, D. E. (1983). Methodology for the human sciences: Systems of inquiry. Albany, NY: State University of New York Press.

Polkinghorne, D. E. (2005). Language and meaning: Data collection in qualitative research. Journal of Counselling Psychology, 52(2), 137-145.

Ponterotto, J. G. (2005a). Qualitative research in counseling psychology: A primer on research paradigms and philosophy of science. Journal of Counselling Psychology, 52(2), 126-136.

Rennie, D. L. (2012). Qualitative research as methodical hermeneutics. Psychological Methods, 17(3), 385-398. doi: $10.1037 / \mathrm{a} 0029250$

Rice, L. N., \& Greenberg, L. S. (1984). Patterns of change: Intensive analysis of psychotherapy process. New York: Guilford Press.

Riemann, G., \& Schu "ze, F. (1991). “Trajectory” as a basic theoretical concept for analyzing suffering and disorderly social process. In D. R. Maines (Ed.), Social organization and social process: Essays in honor of Anselm Strauss (pp. 333-357). New York, NY: De Gruyter.

Sack, H., Schegloff, E. A., \& Jefferson, G. (1974). A simplest systematics for the organization of turn-taking in conversation. Language, 50, 696-735.

Salvatore, S., Gennaro, A., Auletta, A.F., Tonti, M., \& Nitti, M. (2011). Automated method of content analysis: a device for psychotherapy process research. Psychotherapy Research, 22(3), 256-273. doi: 10.1080/10503307.2011.647930

Salvatore, S., \& Valsiner, J. (2010). Between the general and the unique: Overcoming the nomothetic versus idiographic opposition. Theory \& Psychology, 20(6), 817-833. doi: 10.1177/0959354310381156

Salvatore, S., Gennaro, A., Auletta, A. Grassi, R., Rocco, D. (2012). Dynamic Mapping of the Structures of Content in Clinical Settings (DMSC). A new coding system for analysing the patient's narratives. Psychology and Psychotherapy: Theory, Research and Practice, 85(4), 391-423. doi: 10.1111/j.2044-8341.2011.02038.x

Sarracino, D., \& Dazzi, N. (2007). Motivational Areas Rating Scale: Developing a new tool for studying psychotherapy process and outcome. Psychotherapy Research, 17(6), 721732. doi: 10.1080/10503300701303369

Saypol, E., \& Farber, B. A. (2010). Attachment style and patient disclosure in psychotherapy. Psychotherapy Research, 20(4), 462-471. doi: 10.1080/10503301003796821

Schmitt, R. (2005). Systematic Metaphor Analysis as a Method of Qualitative Research. The Qualitative Report, 10(2), 358-
394. Retrieved from http://www.nova.edu/ssss/QR/QR102/schmitt.pdf

Semerari, A., Carcione, A., Dimaggio, G., Falcone, M., Nicolò, G., Procacci, M., \& Alleva, G. (2003). How to evaluate metacognitive function in psychotherapy? The Metacognition assessment scale and its applications. Clinical Psychology and Psychotherapy, 10(4), 238-261

Shrout, P. E., \& Fleiss, J. L. (1979). Intraclass correlations: Uses in assessing rater reliability. Psychological Bulletin, 86(2), 420-428. doi: 10.1037/0033-2909.86.2.420

Silverman, D. (2011). Interpreting qualitative data: A guide to the principles of qualitative research (4th ed.). London: Sage.

Slife, B. D., \& Gantt E. E. (1999). Methodological pluralism: A framework for psychotherapy research. Journal of Clinical Psychology, 55(12), 1453-1465.

Smith, J. A. (1996). Beyond the divide between cognition and discourse: Using interpretative phenomenological analysis in health psychology. Psychology and Health, 11, 161-271. doi: $10.1080 / 08870449608400256$

Steele, H., Steele, M., \& Murphy, A. (2009). Use of the adult attachment interview to measure process and change in psychotherapy. Psychotherapy Research, 19(6), 633-643.

Stiles, W. B., Elliott, R., Llewelyn, S. P., Firth-Cozens, J. A., Margison, F. R., Shapiro, D. A., \& Hardy, G. (1990) Assimilation of problematic experiences by clients in psychotherapy. Psychotherapy: Theory, Research, Practice, Training, 27(3), 411-420.

Stiles, B., Meshot, C., Anderson, T., \& Sloan, W. (1992). Assimilation of problematic experiences: The case of John Jones. Psychotherapy, Research, 2(2), 81-101.

Strauss, A., \& Corbin, J. (1998). Basics of qualitative research: Techniques and procedures for developing grounded theory (2nd ed.). Thousand Oaks, CA: Sage.

Timulak, L. (Ed.). (2008). Research in psychotherapy and counselling (2nd ed.). London: Sage.

Trijsburg, R. W., Frederiks, G. C. F. J., Gorlee, M., Klouwer, E., Den Hollander, A. M., \& Duivenvoorden, H. J. (2002). Development of the Comprehensive Psychotherapeutic Interventions Rating Scale (CPIRS). Psychotherapy Research, 12(3), 287-317. doi: 10.1093/ptr/12.3.287

Valdés, N., Tomicic, A., Pérez, J. C., \& Krause, M. (2010). Sistema de Codificación de la Actividad Terapéutica (SCAT1.0): Dimensiones y categorías de las acciones comunicacionales de pacientes y psicoterapeutas [Therapeutic Activity Coding System (TACS-1.0): Dimensions and Categories of Clients' and Psychotherapists' Communicative Actions]. Revista Argentina de Clínica Psicológica, 19, 117-129. Retrieved from: http://www.clinicapsicologica.org.ar/

Williams, E. N., \& Morrow, S. L. (2009). Achieving trustworthiness in qualitative research: A pan-paradigmatic perspective. Psychotherapy Research, 19, 576-582. doi: 10.1080/10503300802702113

Received December 27, 2012 Accepted December 27, 2012 